\title{
Vellíðan á vinnustað - helgun, starfsánægja og löngun til að hætta í starfi
}

\author{
Hjördís Sigursteinsdóttir ${ }^{1}$
}

\begin{abstract}
Ágrip
Gott starfsumhverfi stuðlar að aukinni vellíðan á vinnustað og góðum starfsanda. Vellíðan í vinnu tengist upplifun starfsfólks á pví að starf peirra sé mikilvægt og gefandi. Markmið pessarar rannsóknar var að skoða helgun í starfi, starfsánægju og löngun til að hætta í starfi meðal starfsfólks íslenskra sveitarfélaga. Settar voru fram fimm rannsóknarspurningar: (1) Hvað mælist helgun há meðal starfsfólksins? (2) Hvað mælist starfsánægja mikil meðal starfsfólksins? (3) Hversu hátt hlutfall starfsfólksins hugsar um að hætta í núverandi starfi? (4) Hvernig tengjast helgun í starfi, starfsánægja og löngun til að hætta í starfi? (5) Er starfsánægja og löngun til að hætta í starfi frábrugðin eftir pví hvort starfsfólk sé helgað í starfi, ekki helgað eða andsnúið í starfi? Rannsóknin byggir á rafrænni spurningalistakönnun sem lögð var fyrir starfsfólk 17 sveitarfélaga á haustdögum 2015. Pað voru 8.942 manns sem fengu spurningalistann sendan í tölvupósti og eftir tvær ítrekanir höfðu 5458 peirra svarað spurningalistanum (svarhlutfall 61\%). Niðurstöðurnar sýna að helgun í starfi mældist 3,7 af 5,0 mögulegum og túlka má niðurstöður helgunar pannig að tæplega priðjungur starfsfólksins var helgað í starfi, 63\% var ekki helgað og 5\% starfsfólksins var andsnúið. Starfsánægja mældist 4,1 og rúmur fjórðungur starfsfólksins var mjög eða frekar sammála pví að hugsa oft um að hætta í núverandi starfi. Niðurstöðurnar sýna jafnframt jákvæð sterk tengsl milli helgunar í starfi og starfsánægju og jákvæð miðlungs sterk tengsl milli helgunar og löngunar til að hætta í starfi. Petta pýðir að eftir pví sem starfsfólk var meira helgað pví meiri ánægju hafði pað af starfinu og löngun til að hætta í starfi var minni. Ljóst er á pessum niðurstöðum að almennt séð pá líður starfsfólki sveitarfélaganna ekki nægilega vel á vinnustaðnum. Niðurstöðurnar gefa pó góðar vísbendingar um hvaða pætti stjórnendur purfa að taka til athugunar til að bæta starfsaðstæður og starfsumhverfið starfsfólkinu til heilla.
\end{abstract}

\section{Abstract}

A good working environment contributes to increased well-being in the workplace and a good working spirit. The aim of this study was to examine work engagement, job satisfaction and intention to leave the job. The study is based on an electronic questionnaire survey submitted to 17 municipal employees in the fall of 2015. There were 8,942 employees who received the questionnaire via email, and after two reminders, the response rate was $61 \%$ (5,458 participants). The results show that measurement for work engagement was 3.7 out of 5.0 and the results indicated that almost one-third of the employees were engaged. Job satisfaction was meas-

1 Hjördís Sigursteinsdóttir er dósent við viðskiptadeild Háskólans á Akureyri. Netfang: hjordis@ unak.is.

This work is licensed under a Creative Commons Attribution 4.0 License.

DOI: https://doi.org/10.24122/tve.a.2020.17.1.3

(C) Tímarit um viðskipti og efnahagsmál

www.efnahagsmal.is 
ured 4.1 out of 5.0, and over a quarter of the employees totally or to some extent agree often thinking about leaving their job. The results also show a strong positive relationship between work engagement and job satisfaction and a medium positive strong relationship between work engagement and intention to leave the job. The results indicate that the more engaged the employees were, they were more satisfied with their job and had less intention to quit their job. It is of great importance to the municipal employees that their working environment is such that it contributes to increased well-being in the workplace and that their experience is that their work is important and rewarding. The results of this study indicate that municipal employees do not perceive their working environment as such. It is, therefore, necessary that the manager take these findings seriously and contribute to better working conditions and work environment for employees.

JEL flokkun: J28; J81; M12; M14]

Lykilorð: Helgun í starfi; starfsánægja; löngun til að hætta í starfi; vellíðan í starfi

Keywords: Engagnement; job satisfaction; turnover intention; well-being at work

\section{Well-being at work - engagament, job satisfaction and turno- ver intentioin}

\section{Inngangur}

Gott starfsumhverfi stuðlar að aukinni vellíðan á vinnustað og góðum starfsanda. Vellíðan í vinnu tengist upplifun starfsfólks á pví að starf peirra sé mikilvægt og gefandi, vinnustaðnum sé vel stýrt og vinnuskipulag gott (Utriainen og Kyngäs, 2011). Vellíðan í vinnu hefur margvíslegar hliðar (Grant, Christianson og Price, 2007; Page og Vella-Brodrick, 2009; Warr, 2013) og ýmsum aðferðum og hugtökum hefur verið beitt til pess að mæla hana. Skilningur okkar á vellíðan á vinnustað, hvað skapar hana og áhrif hennar hefur farið vaxandi síðustu ár í gegnum margvíslegar rannsóknir. Talið er að starfsfólki sem líður ekki vel í starfi hafi meiri tilhneigingu til að vinna illa, mæeta illa og sýna af sér óæskilega hegðun á vinnustaðnum (Spector, 1997).

Starfsánægja er hugtak sem tengt hefur verið vellíðan á vinnustað og líklega pað hugtak sem hvað mest hefur verið rannsakað innan skipulagsheilda (Weiss og Brief, 2001; Wright, 2006). Starfsánægja felur í sér viðhorf til vinnu og er bæði huglægt og tilfinningalegt viðbragð starfsfólks gagnvart starfi sínu. Helgun í starfi er annað hugtak sem tengt hefur verið vellíðan á vinnustað og vakið áhuga fræðimanna sem stunda vinnustaðarannsóknir sem og innan mannauðsstjórnunar síðustu árin (sjá t.d. Bakker, Albrecth og Leiter, 2011; Eldor og Harpaz, 2016; Macey og Schneider, 2008; Rothbard og Patil, 2010; Shuck og Wollard, 2010). Með helgun í starfi er almennt verið að vísa til jákvæðra tengsla starfsfólks við starfið sitt. Vaxandi áhugi innan mannauðsstjórnunar á helgun í starfi er meðal annars til kominn vegna pess að helgun í starfi er talin hafa jákvæð áhrif á árangur skipulagsheilda og frammistöðu starfsmanna (Bakker og Bal, 2010; Halbesleben og Wheeler, 2008; Maycey og Schneider, 2008; Shuck og Wollard, 2010; Xanthopoulou, Bakker, Demerouti og Schaufeli, 2009). Segja má að starfsánægja sé ákveðin tilfinning sem starfsfólk hefur gagnvart starfi sínu á meðan helgun felst í hugarástandinu pegar starfið er unnið (Schaueli og Bakker, 2010). Starfsánægja og helgun eru pví bæði mikilvægir mælikvarðar á framlegð starfsfólks en einnig varðandi hamingju pess og heilsu.

Fisher (2010) bendir á að til pess að meta almenna vellíðan á vinnustað pá purfi að mæla almenna starfsánægju, hollustu og helgun í starfi. Að hans mati meta pessar prjár mælingar almennt viðhorf til skipulagsheildarinnar (raunverulega skuldbindingu), viðhorf til starfsins og pætti pess (starfsánægju) og innri skuldbindingu og ánægju með starfið sjálft (helgun í starfi). Pó ýmsir fræðimenn hafi skoðað starfsánægju (sjá t.d. Kalleberg, 1977; 
Owens 1991; Saari \& Judge 2004; West \& Berman 2009) og helgun í starfi (t.d. Shuck, 2011; Shuck, Ghosh, Zigarmi og Nomon, 2013; Shuck, Reio og Rocco, 2011) út frá margvíslegum sjónarhornum pá er ýmsum spurningum ósvarað varðandi ávinninginn og tengslin milli starfsánægju og helgunar í starfi fyrir skipulagsheildir og vellíðan starfsfólks á vinnustað. Markmið pessarar rannsóknar er að skoða helgun í starfi meðal starfsfólks íslenskra sveitarfélaga í tengslum við starfsánægju og löngunar til að hætta í starfi.

\section{Helgun, starfsánægja og löngun til að hætta í starfi}

Nútíma skipulagsheildir purfa á starfsfólki að halda sem er andlega tengt starfinu, starfsfólki sem er tilbúið og fært um að gefa sig allt í starfið, vinnur af ástríðu, er virkt og áhugasamt og viljugt til að skuldbindast skipulagsheildinni eða með öðrum orðum starfsfólk sem er helgað starfinu (Bakker og Leiter, 2010). Hugtakið helgun í starfi má rekja aftur til ársins 1990 pegar dr. William A. Kahn skilgreindi hugtakið í grein sinni „Psychological Conditions of Personal Engagement and Disengagement at Work" sem birtist í tímaritinu Academy of Management Journal. Par kemur fram að Kahn sótti innblástur í kenningu Ervings Goffman frá árinu 1961 um pað hvernig einstaklingar tengjast daglegum hlutverkum sínum misvel sem hefur svo áhrif á hvernig til tekst að sinna peim. Kahn (1990) yfirfærði pessa kenningu á starfsfólk og vinnu pess en samkvæmt honum pá annað hvort tengist starfsfólk starfi sínu eða aftengist pví á meðan pað vinnur starfið. Starfsfólk sem tengist starfinu er til staðar, líkamlega, vitsmunalega og tilfinningalega og leiðir pað til áhrifaríkari frammistöðu en ella. Рað starfsfólk kallar Kahn helgað starfsfólk. Hins vegar tengist starfsfólk sem leggur sig ekki fram líkamlega, vitsmunalega og tilfinningalega ekki starfinu og pað starfsfólk er ekki helgað starfinu.

Ýmsar skilgreiningar hafa komið fram á hugtakinu helgun í starfi á síðustu árum en algengt er að nota skilgreiningu Bakker og Demerouti (2008) á hugtakinu pegar fjallað er um helgun í starfi. Samkvæmt peim er helgun í starfi jákvætt, gefandi, vinnutengt hugarfar sem einkennist af krafti (e. vigor), eldmóði (e. dedication) og einbeitingu (e. absorption). Með krafti eru Bakker og Demerouti að vísa til mikillar orku og andlegrar seiglu í vinnu, með eldmóði eru pau að vísa til pess að leggja sig allan fram í starfi og sinna starfinu af einlægum áhuga og með einbeitingu eru pau að vísa til pess að vera einbeitt(ur) og niðursokkin(n) í starfið á jákvæðan hátt og eiga erfitt með að slíta sig frá starfinu.

Talið er að starfsfólk sem er helgað sé einbeittara í starfi en starfsfólk sem ekki er helgað (Demerouti og Cropanzano, 2010) og par af leiðandi leggur helgað starfsfólk meiri áherslur á að ná markmiðum skipulagsheildarinnar (Macey og Schneider, 2008; Rothbard og Patil, 2010). Fleiri og fleiri rannsóknir sýna einnig tengsl milli helgunar í starfi og árangurs skipulagheildarinnar, par á meðal frammistöðu starfsfólks (Bakker og Bal, 2010; Harter, Halbesleben og Wheeler, 2008; Schmidt og Hayes, 2002; Maycey og Schneider, 2008; Laschinger og Finegan, 2005; Laschinger and Leiter, 2006; Salanova, Agut og Peiro, 2005; Schaufeli og Bakker, 2004; Shuck og Wollard, 2010; Xanthopoulou, Bakker, Demerouti og Schaufeli, 2009). Pessar rannsóknir gefa til kynna að helgað starfsfólk er skuldbundnara skipulagsheildinni (Hakanen, Bakker og schaufeli, 2006) og vinnur betur (Bakker og Bal, 2010; Xanthopoulou o.fl., 2009). Á sama tíma virðist helgun í starfi leiða til betri andlegrar heilsu og almennrar vellíðanar (Schaufeli og Bakker, 2004; Schaufeli, Taris, van Rhenen, 2008; Xanthopoulou ofl., 2009; Demerouti, Bakker, Nachreiner og Schaufeli, 2001).

Starfsánægja hefur mikil áhrif á pað hvort að starfsfólk prífist á vinnustaðnum eða ekki. Litið er á starfsánægju sem jákvætt eða neikvætt mat starfsfólksins á starfi sínu (Weiss, 2002). Til dæmis skilgreinir Locke (1976) starfsánægju sem endurspeglun á jákvæðu tilfinningalegu ástandi sem er afleiðing af skynjun og reynslu hvers og eins af starfinu. Samkvæmt pessari skilgreiningu má gera ráð fyrir að starfsánægja starfsfólks sveitarfélaga miðist við viðbrögð peirra við starfinu sem peir vinna eða til dæmis kennsluhlutverki grunn- og leikskólakennara (sjá t.d. Skaalvik og Skaalvik, 2010; Zembylas og Papanastasiou, 2004) sem starfa hjá sveitarfélögunum. Locke (1976) bendir á að starfsánægja sé lykil- 
páttur í líðan starfsfólks á vinnustaðnum og hún geti haft áhrif á fjarveru starfsfólks og frammistöðu á vinnustað sem og starfsmannaveltu. Jafnframt sé mikilvægt að starfsfólk viti við hverju megi búast í starfi og pað purfi að vera samræmi á milli parfa starfsfólks og pess hvað pað fær út úr starfinu (Locke, 1976).

Hugtakið starfsánægja líkist hugtakinu vellíðan í starfi. Samkvæmt Grant og félögum (2007, bls. 52) er vellíðan í starfi heildar upplifun starfsfólks af gæðum og virkni í starfi. Sú skilgreining felur í sér prjár víddir vellíðanar; sálræna vellíðan, líkamlega vellíðan og félagslega vellíðan. Vellíðan er lykilpáttur fyrir frammistöðu bæði einstaklingsins og skipulagsheildarinnar. Áhrif slæmrar líðanar endurspeglast í lélegri frammistöðu, fjarveru, viðveru, veikindaleyfum og löngunar til að hætta í starfi (Baptiste, 2008). Annað hugtak sem líkist starfsánægju er hollusta sem hægt er að skilgreina sem að tilheyra skipulagsheildinni og felur í sér áætlun um að starfa lengi innan skipulagsheildarinnar, samsöfnun með gildum og markmiðum skipulagsheildarinnar og vilji til að leggja sig allan í starfið (Porter, Steers, Mowday og Boulian, 1974). Hollusta bindur starfsfólk við skipulagsheildina og dregur par með úr líkum á pví að starfsfólk skipti um vinnustað (Meyer, Becker og Vandenberghe, 2004). Раð hefur verið sýnt fram á pað að starfsánægja hefur áhrif á hollustu í starfi (Bolon, 1997). Einnig er talið að starfsánægja eða starfsóánægja skýri að miklu leyti starfsmannaveltu og löngun til að hætta í starfi (Chan o.fl., 2008; Coomber og Barriball, 2007, De Gieter, Hofmans og Pepermans, 2011; Lambert, Hogan og Barton, 2001; Tsai og Wu 2010).

Pó ýmsar rannsóknir hafa skoðað helgun í starfi, starfsánægju og löngun til að hætta í starfi pá hafa engar rannsóknir verið birtar á pessum páttum meðal starfsfólks íslenskra sveitarfélaga svo vitað sé. Vinnustaðir íslenskra sveitarfélaga eru margir hverjir stórir kvenna vinnustaðir og stórir hópar sem hafa menntað sig sérstaklega til að sinna ákveðnum störfum innan sveitarfélaganna. Má par til dæmis nefna alla leik- og grunnskólakennara sem starfa hjá sveitarfélögunum. Рað er pví áhugavert að skoða hversu helgað starfsfólk íslenskra sveitarfélaga er og hvernig helgun í starfi tengist starfsánægju og löngunar til að hætta í starfi. Settar voru fram eftirfarandi fimm rannsóknarspurningar: (1) Hvað mælist helgun há meðal starfsfólksins? (2) Hvað mælist starfsánægja mikil meðal starfsfólksins? (3) Hversu hátt hlutfall starfsfólksins hugsar um að hætta í núverandi starfi? (4) Hvernig tengjast helgun í starfi, starfsánægja og löngun til að hætta í starfi? (5) Er starfsánægja og löngun til að hætta í starfi frábrugðin eftir pví hvort starfsfólk sé helgað í starfi, ekki helgað eða andsnúið í starfi?

\section{Gögn og aðferðir}

Pessi grein byggir á rannsókninni Liððan, heilsa og starfstengd viðhorf starfsfólks íslenskra sveitarfélaga. Um er að ræða langtíma panel rannsókn par sem fylgst hefur verið með heilsu, líðan og starfstengdum viðhorfum starfsfólks sveitarfélaga frá árinu 2010. Í pessari grein er notuð fyrirlögn frá árinu 2015 og helgun starfsfólks skoðuð í tengslum við starfsánægju og löngun til að hætta í starfi.

\subsection{Framkvæmd}

Netföngum starfsfólks var safnað meðal forsvarsmanna pátttökusveitarfélaganna en pau skilyrði voru sett að starfsmaður varð að vera eldri en 18 ára og vera í að minnsta kosti hálfu starfi (50\% stöðugildi eða hærra) hjá sveitarfélaginu. Beiðni um pátttöku í rannsókninni var send í tölvupósti á haustdögum 2015 og fylgt eftir með tveimur ítrekunum til peirra sem ekki höfðu svarað spurningalistanum. Til pess að taka pátt pá purfti viðtakandi að smella á par til gerða slóð sem opnaði spurningalistann. Með pví að gera pað pá sampykkti viðtakandi pátttöku sína í rannsókninni og gat sent inn nafnlaust svar. Áréttað var að öllum var frjálst að hafna pátttöku í rannsókninni án útskýringa og einnig höfðu pátttakendur val um að sleppa öllum peim spurningum sem peir vildu ekki svara. 


\subsection{Pátttakendur}

Pátttakendur í rannsókninni koma frá 17 sveitarfélögum víðsvegar um landið, Akureyri, Árborg, Borgarbyggð, Fjallabyggð, Fljótdalshéraði, Garðabæ, Grindavík, Hafnarfirði, Hveragerði, Hornafirði, Isafirði, Kópavogi, Mosfellsbæ, Norðurpingi, Reykjanesbæ, Seltjarnarnesi og Vestmannaeyjum.

Spurningalistinn var sendur á 8.942 starfsmenn og svöruðu 5458 peirra spurningalistanum að öllu eða miklu leyti (svarhlutfall 61\%). Mikill meirihluti svarenda voru konur eða 81,7\% enda er kynjahlutfall innan margra vinnustaða sveitarfélaganna mjög skekkt. Svarendur endurspegla vel kynjaskiptingu starfsfólks sveitarfélaga. Rúmlega helmingur svarenda var á aldursbilinu 31-50 ára og fjórðungur á aldrinum 51-60 ára. Nokkuð fleiri voru 30 ára og yngri en 61 árs og eldri eða 12,9\% á móti 10,8\%. Í langflestum tilvikum voru svarendur giftir eða í sambúð eða 80,9\%.

\subsection{Mælitæki}

Spurningalistinn sem var notaður í rannsókninni samanstóð af premur stöðluðum mælikvörðum á heilsu og líðan starfsfólks á vinnustöðum. Í fyrsta lagi var um að ræða Q12 matslista Gallup, í öðru lagi Norræna spurningalistann um sálfélagslega pætti í vinnunni í pýðingu Hólmfríðar K. Gunnarsdóttur og í priðja lagi spurningalista Lýðheilsustöðvar um heilsu og líðan Íslendinga. Í pessari grein verður fjallað um niðurstöður í tengslum við spurningar varðandi helgun í starfi, starfánægju og löngun til að hætta í starfi. Flestar spurningarnar eru mældar á fimm punkta Líkert-kvarða. Ákveðið var að gefa sér að pað sé jafnt bil á milli prepa í kvarðanum og á peirri forsendu var reiknað meðaltal.

Helgun í starfi var mæld með Q12 matslista Gallup en hann mælir hversu vel vinnustaðurinn mætir tólf lykilpörfum starfsfólks sem snúa að daglegri reynslu pess. Um er að ræða eftirfarandi 12 fullyrðingar; (1) „Ég veit til hvers er ætlast af mér í starfi mínu“, (2) „Ég hef pau tæki og gögn sem nauðsynleg eru til að sinna starfi mínu vel“, (3) „Ég hef tækifæri til pess í vinnunni að gera pað sem ég kann best á hverjum degi“, (4) „Ég hef fengið hrós eða viðurkenningu fyrir vel unnin störf á síðustu vikum“, (5) „Yfirmaður minn eða vinnufélagi ber umhyggju fyrir mér sem einstaklingi“, (6) „,Yfirmaður minn eða félagi hvetur mig til að próast í starfi“, (7) „Álit mitt skiptir máli í vinnunni“, (8) „Mér finnst starfsemi og hlutverk vinnustaðarins gefa til kynna að starf mitt sé mikilvægt“, (9) „Vinnufélagar mínir leggja sig alla fram við að skila vel unnu verki“, (10) „Ég á góða(n) vinkonu/vin í vinnunni“, (11) „Á síðastliðnum 6 mánuðum hefur yfirmaður eða vinnufélagi rætt við mig um frammistöðu mína í starfi“, (12) „Ég hafði tækifæri til pess að læra að próast í starfi á síðastliðnum 12 mánuðum“. Gefnir voru fimm svarmöguleikar, frá (1) mjög ósammála og að (5) mjög sammála. Alfastuðull fyrir pessar 12 fullyrðingar var 0,87. Fyrstu tvær fullyrðingarnar meta grunnparfir í starfi, p.e. pekkingu og tæki/úrræði starfsfólks til að sinna starfinu, (alfastuðull var 0,78). Fullyrðingar 3-6 snúa að pví hvernig starfsfólk hugsar um eigið framlag og spáir í pað hvernig yfirmenn og vinnufélagar sjá pað og hvernig pau meta vinnuframlag peirra, (alfastuðull var 0,79). Fullyrðingar 7-10 snúa að pví hvernig starfsfólk metur tengsl sín við hópinn og vinnustaðinn (alfastuðull var 0,66) og fullyrðingar 11-12 meta framgang í starfi (aflastuðull var 0,74). Helgun í starfi er skipt upp í prjú stig eftir pví hversu mikla eða litla helgun starfsfólk hefur; (1) helgað, (2) ekki helgað og (3) andsnúið (Gallup Inc., 2013).

Starfsánægja var mæld með fullyrðingunni; „Pegar á heildina er litið er ég ánægð(ur) í starfi mínu“. Gefnir voru fimm svarmöguleikar, frá (1) mjög ósammála og að (5) mjög sammála.

Löngun til að hætta í starfi var mæld með fullyrðingunni; „Ég hugsa oft um að hætta í núverandi starfi“. Gefnir voru fimm svarmöguleikar, frá (1) mjög ósammála og að (5) mjög sammála. Par sem pessi fullyrðing snýr öfugt við aðrar fullyrðingar pá var henni snúið við í úrvinnslunni pannig að 1 fékk gildið 5, 2 fékk gildið 4 o.s.frv. Petta pýðir að hærra gildi táknar minni löngun til að hætta í starfi. 


\subsection{Gagnagreining}

Niðurstöðurnar eru settar fram sem fjöldatölur, hlutföll, meðaltöl og staðalfrávik og reiknað öryggisbil fyrir hlutföll. Til pess að skoða mun á meðalgildi helgunar í starfi, starfsánægju og löngunar til að hætta í starfi eftir kyni og hjúskaparstöðu var notað óháð t-próf og áhrifastuðullinn metinn með eta gildi $\left(\eta^{2}\right)$. Einbreytu dreifigreining var notuð til pess að skoða mun á meðalgildi helgunar í starfi, starfsánægju og löngunar til að hætta í starfi eftir aldri. Eftiráprófið Tukey HSD var notað til að skoða milli hvaða aldurhópa kom fram munur ef einhver og áhrifastuðullinn metinn með eta gildi. Til pess að túlka eta gildið í óháða t-prófinu og dreifigreiningunni var notuð skilgreining Cohens (1988, bls. 284-287) par sem 0,01-0,05 eru lítil áhrif, 0,06-0,13 miðlungs áhrif og 0,14 og hærra mikil áhrif.

Helgun í starfi var einnig skipt í prjá hópa, (1) starfsfólk sem er helgað í starfi, (2) starfsfólk sem er ekki helgað og (3) starfsfólk sem er andsnúið starfinu. Til pess að skoða hvort fram kom munur á pessum premur hópum eftir kyni, aldri eða hjúskaparstöðu var notað kí-kvaðrat próf og áhrifastuðullinn metinn með Cramér's V. Styrkleiki tengsla fyrir kyn og hjúskaparstöðu var túlkuð sem lítil $=0,7$, miðlungs $=0,21$ og sterk $=0,35$ en fyrir aldur sem lítil = 0,06, miðlungs = 0,17 og sterk =0,29 (sjá nánar Gravetter og Wallnau (2004, bls. 605).

Til að skoða fylgni milli helgunar í starfi, starfsánægju og löngunar til að hætta í starfi var notað Pearson $r$ fylgni próf. Notuð var skilgreining Cohens $(1988$, bls. 79-81) til að meta hvort um veik $(0,10-0,29)$, miðlungs $(0,30-0,49)$ eða sterk tengsl $(0,50-1,0)$ væri að ræða.

Að lokum var skoðað hvort munur væri á starfsánægju og löngunar til að hætta í starfi eftir pví hvort starfsfólk var helgað í starfi, ekki helgað eða andsnúið í starfi með einbreytu dreifigreiningu og Tukey HSD eftiráprófi. Áhrifastuðullinn var mældur með eta gildi og stuðst við túlkun Cohens (1988, bls. 284-287) um styrkleika tengsla par sem 0,01-0,05 eru lítil áhrif, 0,06-0,13 miðlungs áhrif og 0,14 og hærra mikil áhrif. Tölfræði var unnin í SPSS 22.0 og marktæknikrafa var 0,05 .

\section{Niðurstöður}

Tafla 1 sýnir meðalgildi fyrir helgun í starfi, starfsánægju og löngun til að hætta í starfi eftir kyni, aldri og hjúskaparstöðu. Meðalgildi fyrir helgun í starfi var 3,69 af 5,0 mögulegum. Óháð t-próf var notað til að skoða mun milli kvenna og karla og helgunar í starfi. Fram kom marktækur munur milli kvenna og karla $\left(t_{(4712)}=7,2, p<0,05\right)$ par sem meðalgildi kvenna $(M=3,74, S F=0,69)$ fyrir helgun í starfi var hærra en meðalgildi karla $(M=3,54, S F$ $=0,69)$. Samkvæmt almennu viðmiði Cohens (1988) skýrði kyn pó aðeins mjög lítinn hluta af breytileika helgunar í starfi $\left(\eta^{2}=0,01\right)$.

Einnig má sjá að meðalgildi helgunar í starfi var lægra meðal eldra starfsfólks en yngra $\left(F_{(4,4492)}=4,49, p<0,001\right)$. Eftiráprófið sýndi mun á starfsfólki í aldurshópnum yngri en 30 ára $(M=3,80, S F=0,67)$ og starfsfólki í aldurshópunum 51-60 ára $(M=3,67, S F=0,71)$ og 61 árs og eldri $(M=3,68, S F=0,70)$. Samkvæmt almennu viðmiði Cohens (1988) skýrði aldur pó mjög lítinn hluta af breytileika svara helgunnar í starfi $\left(\eta^{2}<0,01\right)$. Ekki kom fram munur á helgun í starfi eftir hjúskaparstöðu starfsfólks $\left(t_{(4655)}=0,4, p>0,05\right)$.

Meðalgildi fyrir starfsánægju var 4,08 af 5,0 mögulegum. Fram kom marktækur munur á starfsánægju eftir pví hvort um karl eða konu var að ræða $\left(t_{(4839)}=4,45 ; p<0,05\right)$ par sem meðalgildi starfsánægju var hærra meðal kvenna $(M=4,11, S F=0,87)$ en meðalgildi karla $(M=3,96, S F=0,94)$. Samkvæmt almennu viðmiði Cohens (1988) skýrði kyn pó aðeins mjög lítinn hluta af breytileika starfsánægju $\left(\eta^{2}=0,01\right)$.

Einnig mátti sjá að meðalgildi fyrir starfsánægju var hærra fyrir eldra starfsfólk en yngra ef frá er talið starfsfólk í yngsta aldurshópnum $\left(F_{(4,4614)}=7,34, p<0,05\right)$. Eftiráprófið sýndi að meðalgildi fyrir starfsánægja var lægra meðal starfsfólks í aldurshópnum 31-40 ára $(M=4,0, S F=0,91)$ en öðrum aldurshópum $(M=4,05-4,21, S F=0,81-0,91)$ og meðalgildi fyrir starfsfólk í elsta aldurshópnum $(M=4,21, S F=0,81)$ var hærra en meðalgildi fyrir 
starfsfólk í aldurshópnum 41-50 ára $(M=4,05, S F=0,88)$. Samkvæmt almennu viðmiði Cohens (1988) skýrði aldur pó aðeins mjög lítinn hluta af breytileika starfsánægju $\left(\eta^{2}<0,01\right)$.

Tafla 1. Helguní starfi, starfsánægja og löngun til að hætta eftir kyni, aldri og hjúskaparstöðu

\begin{tabular}{|c|c|c|c|c|c|c|c|c|}
\hline & \multirow[b]{2}{*}{ Fjöldi } & \multirow[b]{2}{*}{$\%$} & \multicolumn{2}{|c|}{ Helgun í starfi } & \multicolumn{2}{|c|}{ Starfsánægja } & \multicolumn{2}{|c|}{$\begin{array}{l}\text { Löngun til að } \\
\text { hætta í starfi }\end{array}$} \\
\hline & & & M & SF & $\mathrm{M}$ & SF & $\mathrm{M}$ & SF \\
\hline Heild: & 5458 & & 3,69 & 0,70 & 4,08 & 0,88 & 3,53 & 1,27 \\
\hline \multicolumn{9}{|l|}{ Kyn: } \\
\hline Karlar & 977 & 18,3 & 3,54 & 0,69 & 3,96 & 0,94 & 3,49 & 1,28 \\
\hline Konur & 4372 & 81,7 & 3,73 & 0,69 & 4,11 & 0,87 & 3,55 & 1,27 \\
\hline \multicolumn{9}{|l|}{ Aldursflokkar } \\
\hline$<30$ & 654 & 12,9 & 3,80 & 0,67 & 4,14 & 0,92 & 3,72 & 1,28 \\
\hline $31-40$ & 1209 & 23,8 & 3,74 & 0,68 & 4,00 & 0,91 & 3,44 & 1,30 \\
\hline $41-50$ & 1397 & 27,5 & 3,71 & 0,70 & 4,05 & 0,88 & 3,44 & 1,26 \\
\hline $51-60$ & 1178 & 25,0 & 3,67 & 0,71 & 4,13 & 0,86 & 3,60 & 1,64 \\
\hline$>60$ & 637 & 10,8 & 3,68 & 0,70 & 4,21 & 0,81 & 3,77 & 1,25 \\
\hline \multicolumn{9}{|l|}{ Hjúskaparstaða: } \\
\hline Hjónaband/sambúð & 4241 & 80,9 & 3,71 & 0,69 & 4,08 & 0,87 & 3,53 & 1,27 \\
\hline Einhleyp/ur & 1003 & 19,1 & 3,69 & 0,72 & 4,09 & 0,91 & 3,57 & 0,82 \\
\hline
\end{tabular}

Meðalgildi fyrir löngun til að hætta í starfi var 3,53 af 5,0 möguleikum. Ekki kom fram munur á löngun til að hærra í starfi eftir pví hvort um konu $(M=3,55, S F=1,27)$ eða karl $(M=3,49, S F=1,28)$ var að ræða $\left(t_{(5347)}=0,78, p>0,05\right)$ eða hvort viðkomandi var einhleypur $(M=3,57, S F=0,82)$ eða í hjónabandi eða sambúð $\left(M=3,53, S F=1,27 ;\left(t_{(5242)}=0,15, p>0,05\right)\right.$. Hins vegar kom fram munur á löngun til að hætta í starfi eftir aldurshópum $\left(F_{(4,4587)}=11,11\right.$, $p<0,05)$. Eftiráprófið sýndi að meðalgildi fyrir löngun til að hætta í starfi meðal starfsfólks í aldurshópunum 31-50 ára $(M=3,44, S F=1,30$ og 1,26) var lægra en meðal starfsfólks í öllum öðrum aldurshópum ( $\mathrm{M}=3,60-3,77, \mathrm{SF}=1,25-1,64)$. Samkvæmt almennu viðmiði Cohens (1988) skýrði aldur pó aðeins lítinn hluta af breytileika löngunar til að hætta í starfi $\left(\eta^{2}=0,01\right)$.

Niðurstöðurnar sýndu jafnframt að 8,4\% (+-0,7\%) starfsfólksins var mjög sammála pví að hugsa oft um að hætta í núverandi starfi og 16,5\% (+-1,0\%) til viðbótar var mjög sammála pví. Sjá mátti að 22,2\% (+-2,3\%) starfsfólks á aldrinum 31-40 ára var mjög eða frekar sammála pví að hugsa oft um að hætta í núverandi starfi og 19,8\% (+-2,1\%) starfsfólks á aldrinum 41-50 ára.

\subsection{Helgun í starfi}

Mynd 1 sýnir niðurstöður fyrir fullyrðingarnar um helgun í starfi. Fyrstu tvær spurningarnar snúa að grunnpörfum starfsfólksins. Í flestum tilvikum vissi starfsfólk hvaðætlast var til af pví í starfi (78\% sammála, +-1,1\%) en færri höfðu pau tæki og gögn sem nauðsynleg eru til að sinna starfinu vel (60\% sammála, +-1,3\%). Pessar niðurstöður sýna að grunnpörfum starfsfólksins er ekki nægilega vel sinnt. Næstu fjórar spurningar snúa að eigin framlagi starfsfólksins og hvernig pað lítur á sitt framlag. Um 64\% (+-1,3\%) starfsfólksins var sammála pví að yfirmaður eða vinnufélagi peirra bæru umhyggju fyrir peim sem einstaklingi og pað fengi tækifæri til pess í vinnunni að gera pað sem pað kann best á hverjum degi. Aðeins 37\% (+-1,3\%) starfsfólksins var sammála pví að hafa fengið hrós eða viðurkenningu fyrir vel unnin störf á síðustu vikum og fimmtungur (+-1,2\%) var mjög ósammála peirri fullyrðingu. 


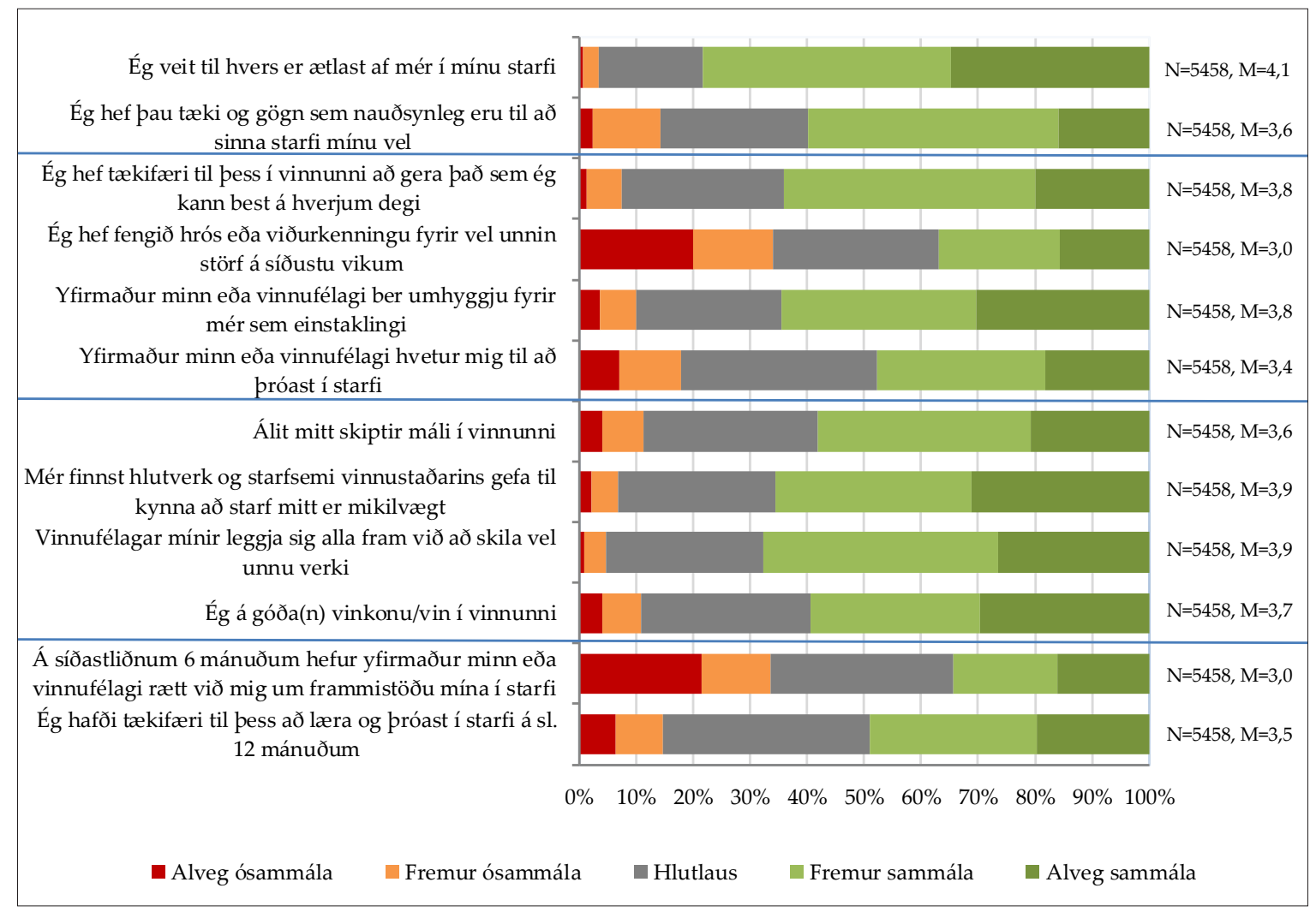

Mynd 1. Niðurstöður fyrir fullyrðingarnar 12 sem mæla helgun í starfi

Tæplega helmingur starfsfólksins $(48 \%,+-1,3 \%)$ var sammála pví að yfirmaður eða vinnufélagi hvetji pað til að próast í starfi. Pessar niðurstöður sýna að starfsfólkið taldi sig vanta viðurkenningu og hrós í starfi sem og hvatningu frá yfirmönnum og vinnufélögum. Spurningar 7-10 snúa að tengslum starfsfólks við vinnustaðinn en sjá mátti að tæplega $68 \%(+-1,2 \%)$ voru sammála pví að vinnufélagarnir leggi sig alla fram við að skila vel unnu verki og tæp $66 \%(+-1,3 \%)$ voru sammála pví að hlutverk og starfsemi vinnustaðarins gæfi til kynna að starf peirra sé mikilvægt. Nokkuð færri eða 59\% (+-1,3\%) voru sammála pví að eiga góða vinkonu eða góðan vin í vinnunni og um 58\% (+-1,3\%) töldu að álit peirra skipti máli í vinnunni. Niðurstöðurnar sýndu að starfsfólkið er ekki með sterka tengingu við vinnustaðinn. Síðustu tvær spurningarnar snúa að samræðum um framvindu í starfi og starfspróun. Tæplega helmingur starfsfólksins (49\%,+-1,3\%) var sammála pví að hafa fengið tækifæri á síðastliðnum 12 mánuðum til að próast í starfi. Aðeins rúmlega priðjungur starfsfólksins $(34 \%,+-1,2 \%)$ var sammála pví að á síðustu 6 mánuðum hafi yfirmaður eða vinnufélagi rætt við pað um frammistöðu pess í starfi og tæp 22\% (+-1,1\%) var mjög ósammála peirri fullyrðingu. Heilt yfir má segja að starfsfólk taldi sig ekki hafa haft mikil tækifæri til próast í starfi og pað vanti að fá endurgjöf á frammistöðu sína.

Niðurstöður fyrir helgun í starfi voru flokkaðar í prjá hópa, starfsfólk sem var helgað í starfi, starfsfólk sem var ekki helgað í starfi og starfsfólk sem var andsnúið starfinu. Mynd 2 sýnir niðurstöður pessarar flokkunar eftir kyni, aldri og hjúskaparstöðu. Sjá má að samkvæmt pessari flokkun var tæplega priðjungur starfsfólksins (+-1,2\%) helgað í starfi, langflestir voru ekki helgaðir eða 63\% (+-1,3\%) og tæp 5\% (+-0,6\%) var andsnúið starfinu. 


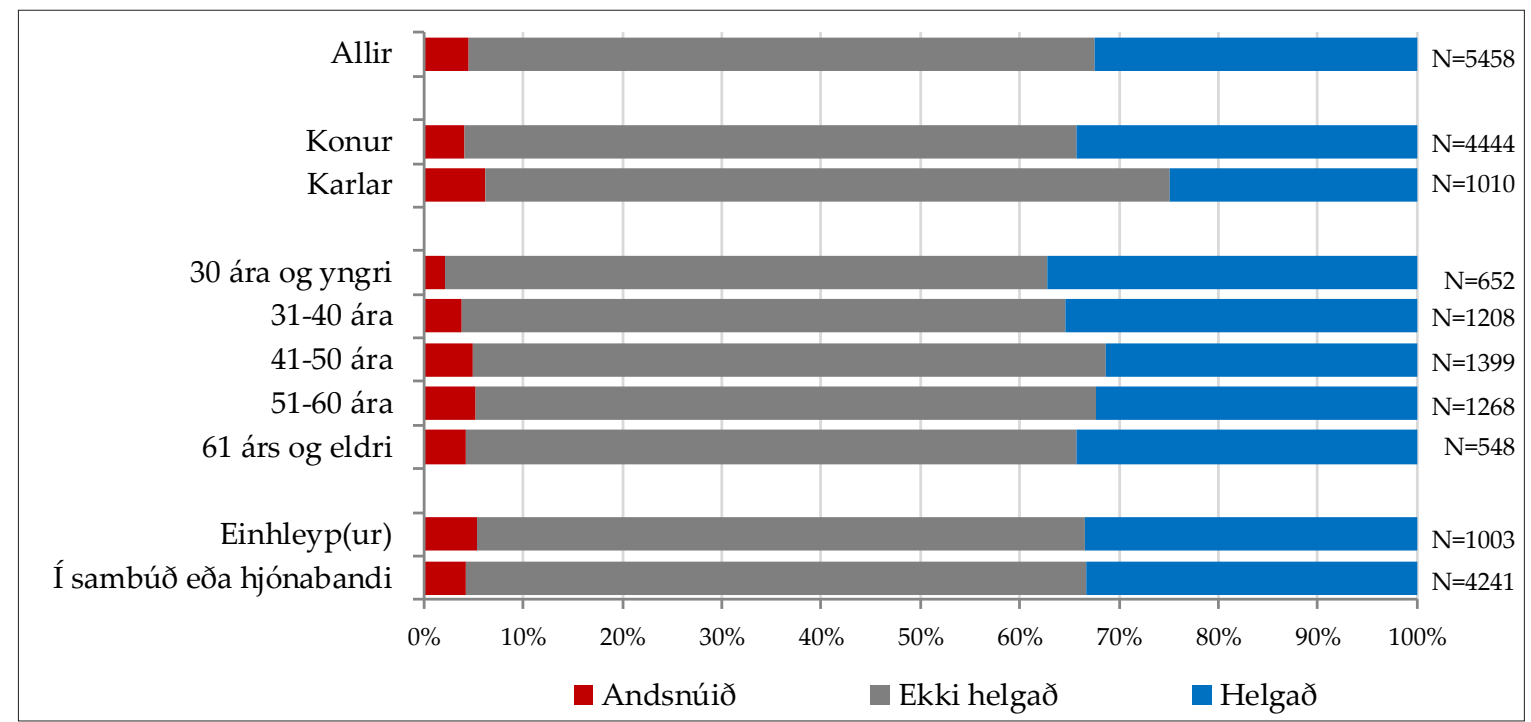

Mynd 2. Helgun í starfi eftir kyni, aldri og hjúskaparstöðu

Notað var kí-kvaðratpróf til að skoða prískipta flokkun helgunar í starfi og hvort munur væri eftir kynferði, aldri eða hjúskaparstöðu. Konur voru í meira mæli helgaðar í starfi en $\operatorname{karlar}\left(\chi^{2}(2, \mathrm{~N}=5454)=36,5 ; p<0,05\right.$, Cramver's $\left.V=0,94\right)$. Rúm 34\% (+-1,4\%) kvenna mældust helgaðar í starfi á móti 25\% (+-2,7\%) karla og 6\% (+-1,5\%) karla mældist andsnúnir starfinu á móti $4 \%(+-0,6 \%)$ kvenna. Einnig kom í ljós munur á helgun í starfi eftir aldri

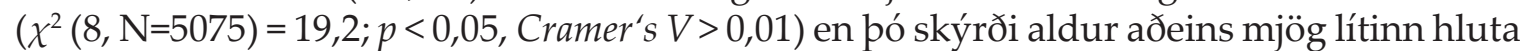
af breytileika milli pess hvort starfsfólk var helgað, ekki helgað eða andsnúið. Ekki kom fram munur á helgun í starfi eftir hjúskaparstöðu starfsfólksins $\left(\chi^{2}(2, \mathrm{~N}=4657)=4,2 ; p>\right.$ $0,05)$.

\subsection{Tengsl helgunar, starfsánægju og löngunar til að hætta í starfi}

Skoðuð var fylgni milli helgunar í starfi, starfsánægju og löngunar til að hætta í starfi. Niðurstöðurnar sýna jákvæð sterk tengsl milli helgunar í starfi og starfsánægju $(r=0,55$, $\mathrm{N}=5458, p<0,05)$. Раð er að segja, eftir pví sem meðalgildi helgunar í starfi mældist hærra pví hærra mældist meðalgildi starfsánægju. Pað kemur pví ekki á óvart pótt jákvæð miðlungs sterk tengsl hafi einnig mælst milli helgunar í starfi og löngunar til að hætta í starfi $(r=0,43, \mathrm{~N}=5458, p<0,05)$ pannig að hærra meðalgildi helgunar í starfi pýddi hærra meðalgildi á löngun til að hætta í starfi sem túlkast sem minni löngun til að hætta í starfi.

Einhliða dreifigreining var notuð til að skoða hvort munur væri á starfsánægju og löngunar til að hætta í starfi eftir pví hvort starfsfólk var helgað starfinu, ekki helgað eða andsnúið starfinu. Niðurstöðurnar eru sýndar í töflu 2. Fram kom marktækur munur eftir flokkun helgunar og starfsánægju $\left(F_{(2,5455)}=770,4, p<0,05\right)$. Eftiráprófið (Tukey HSD) sýndi að meðalgildi starfsánægju mældist mun hærra hjá starfsfólki sem flokkast sem helgað í starfi $(M=4,58, S F=0,6)$ en pess sem ekki var helgað $(M=3,79, S F=0,9)$ eða andsnúið starfinu $(M=2,81, S F=1,0)$. Samkvæmt almennu viðmiði Cohens (1988) skýrði priggja flokkun helgunar í starfi stóran hluta af breytileika í starfsánægju $\left(\eta^{2}=0,26\right)$.

Tafla 2. Starfsánægju og löngun til að hætta í starfi eftir pví hvort starfsfólk er helgað í starfi, ekki helgað eða andsnúið

\begin{tabular}{lcc}
\hline & $\begin{array}{c}\text { Starfsánægja } \\
\text { M (SF) }\end{array}$ & $\begin{array}{c}\text { Löngun til að hætta í starfi } \\
\text { M (SF) }\end{array}$ \\
\hline Starfsfólk helgað í starfi & $4,58(0,6)$ & $4,1(1,0)$ \\
\hline Starfsfólk ekki helgað í starfi & $3,79(0,9)$ & $3,2(1,2)$ \\
\hline Starfsfólk andsnúið í starfi & $2,81(1,0)$ & $2,4(1,3)$ \\
\hline
\end{tabular}


Einnig kom í ljós marktækur munur á löngun til að hætta í starfi eftir pví hvort starfsfólk var helgað starfinu, ekki helgað eða andsnúið starfinu $\left(F_{(2,5455)}=439,7, p<0,05\right)$. Eftiráprófið sýndi að meðalgildi löngunar til að hætta í starfi hjá peim sem flokkast sem helgaðir í starfi $(\mathrm{M}=4,1, \mathrm{SF}=1,0)$ var mun hærra en meðalgildi peirra sem ekki voru helgaðir í starfi $(\mathrm{M}=$ $3,2, \mathrm{SF}=1,2)$ og peirra sem voru andsnúnir starfinu $(\mathrm{M}=2,4, \mathrm{SF}=1,3)$. Samkvæmt almennu viðmiði Cohens (1988) skýrði priggja flokkun helgunar í starfi stóran hluta af breytileika í löngun til að hætta í starfi $\left(\eta^{2}=0,15\right)$.

\section{Umræður og ályktun}

Í pessari rannsókn var helgun í starfi skoðuð ásamt starfsánægju og löngun til að hætta í starfi. Settar voru fram eftirfarandi fimm rannsóknarspurningar: (1) Hvað mælist helgun há meðal starfsfólksins? (2) Hvað mælist starfsánægja mikil meðal starfsfólksins? (3) Hversu hátt hlutfall starfsfólksins hugsar um að hætta í núverandi starfi? (4) Hvernig tengjast helgun í starfi, starfsánægja og löngun til að hætta í starfi? (5) Er starfsánægja og löngun til að hætta í starfi frábrugðin eftir pví hvort starfsfólk er helgað í starfi, ekki helgað eða andsnúið í starfi? Niðurstöðurnar sýna að helgun mældist 3,7 af 5,0 mögulegum, hún mældist hærri meðal kvenna en karla og hæst meðal starfsfólks 30 ára og yngri. Pó sýndu niðurstöðurnar að bæði kyn og aldur skýrðu aðeins mjög lítinn hluta af breytileika í dreifingu svara varðandi helgun í starfi .

Með pví að flokka helgun í starfi í prjá hópa kom í ljós að tæplega priðjungur starfsfólksins var helgað í starfi, 63\% var ekki helgað og 5\% starfsfólksins var andsnúið. Раð аð aðeins priðjungur starfsfólksins mælist helgað í starfi er áhyggjuefni, sérstaklega í ljósi pess að hjá sveitarfélögunum eru stórir hópar starfsfólks sem hefur menntað sig sérstaklega til að sinna pví starfi sem pað er í. Má par nefna leikskólakennara og grunnskólakennara. Litið til einstakra spurninga í matskvarðanum fyrir helgun í starfi vekur athygli að aðeins ein fullyrðing mældist yfir 4,0 af 5,0 möguleikum og pað var fullyrðingin „Ég veit til hvers er ætlast af mér í starfi mínu“ en pó sýndu niðurstöðurnar pað að grunnpörfum starfsfólksins var ekki nægilega vel sinnt. En pað kom líka í ljós að starfsfólkið taldi sig vanta viðurkenningu og hrós í starfi og meiri hvatningu frá bæði yfirmönnum og vinnufélögum. Petta eru hlutir sem hægt er að laga á tiltölulega auðveldan hátt án pess að pað purfi að kosta miklu til. Hins vegar sýna niðurstöðurnar líka að starfsfólkið er ekki með nægilega sterka tengingu við vinnustaðinn, álit pess skipti ekki máli og margir hverjir eiga ekki vin eða vinkonu á vinnustaðnum. Mikilvægt er að skoða hvað pað er í staðblæ vinnustaðarins sem gerir pað að verkum að starfsfólk nái ekki nægilegri tengingu við vinnustaðinn en tenging við vinnustaðinn skiptir miklu máli varðandi vellíðan pess í starfi. Niðurstöðurnar sýna einnig að starfsfólkið taldi sig ekki hafa haft mikil tækifæri til að próast í starfi og frammistaða í starfi verið lítið rædd af yfirmanni og vinnufélögum en pað er mjög mikilvægt fyrir starfsfólkið einmitt að fá endurgjöf á starf sitt og tækifæri til að próast í starfi. Utriainen og Kyngäs (2011) benda á að vellíðan í vinnu tengist upplifun starfsfólks á pví að starf peirra sé mikilvægt og gefandi, góð stjórnun sé á vinnustaðnum og gott vinnuskipulag. Í pví ljósi má túlka pessar niðurstöður pannig að starfsfólki sveitarfélaganna líði ekki nægilega vel á vinnustaðnum. Pessar niðurstöður gefa pó góðar vísbendingar um hvaða pætti stjórnendur purfa að taka til athugunar til að bæta starfsaðstæður og starfsumhverfi starfsfólksins pannig að pví líði sem best í starfi.

Starfsánægja mældist 4,1 af 5,0 mögulegum og starfsánægja mældist hærri meðal kvenna en karla og hæst meðal starfsfólks sem er eldra en 60 ára. Pó sýna niðurstöðurnar einnig að kyn og aldur skýra mjög lítinn hluta af dreifingu svara fyrir starfsánægju. Túlka má pessar niðurstöður sem að viðhorf starfsfólksins til vinnunnar sé gott pó pað tengist ekki nægilega vel starfi sínu eins og niðurstöður helgunar í starfi gefa til kynna. Eins og Schaueli og Bakker (2010) tala um pá mælir starfsánægja pá tilfinningu sem starfsfólk hefur gagnvart starfinu en helgun felst í hugarástandinu pegar starfið er unnið. Locke (1976) einn helsti fræðimaður starfsánægju bendir á að einn af lykilpáttum í líðan starfs- 
fólks á vinnustað sé starfsánægja og að starfsánægja hafi áhrif á fjarveru starfsfólks og frammistöðu á vinnustað sem og starfsmannaveltu. Niðurstöður pessarar rannsóknar sýndu að rúm $8 \%(+-0,7 \%)$ starfsfólksins var mjög sammála pví að hugsa oft um að hætta í núverandi starfi og tæp 17\% (+-1,0\%) frekar sammála pví. Aðallega var pað starfsfólk á aldrinum 31-50 ára sem hugsaði meira um að hætta í núverandi starfi en starfsfólk í öðrum aldurhópum. Petta pýðir að um fjórðungur alls starfsfólksins (+-1,0\%) var sammála pví að hugsa um að hætta í núverandi starfi sem vekur athygli í ljósi pess hve almenn starfsánægja mælist há en pó ekki ef horft er til priggja flokka helgunar í starfi.

Fram komu jákvæð sterk tengsl milli helgunar í starfi og starfsánægju og jákvæð miðlungs sterk tengsl milli helgunar og löngunar til að hætta í starfi. Petta pýðir að eftir pví sem starfsfólk var meira helgað pví meiri ánægju hafði pað af starfinu og löngun til að hætta í starfi var minni. Рað starfsfólk sem var helgað í starfi mældist með mestu starfsánægjuna og minnstu löngun til að hætta í starfi og pað starfsfólk sem var andsnúið mældist með minnstu starfsánægjuna og mestu löngun til að hætta í starfi. Eins og fram hefur komið pá bendir Fisher (2010) á að til pess að meta almenna vellíðan á vinnustað pá purfi að mæla almenna starfsánægju, hollustu og helgun í starfi. Pó hollusta í starfi hafi ekki verið mæld í pessari rannsókn pá má samt sjá að starfsfólk tengdist ekki vinnustaðnum nægilega vel sem bendir til pess að raunveruleg skuldbinding til starfsins sé ekki nægilega vel til staðar. Meyer, Becker og Vandenberghe (2004) telja að hollusta bindi starfsfólkið við vinnustaðinn pannig að skortur á hollustu auki líkur á löngun til að hætta í starfi.

Helsta takmörkun rannsóknarinnar er að hér er aðeins horft á einn mælipunkt sem lýsir vinnuskipulaginu og starfsumhverfinu á peim tímapunkti. Mikilvægt er að halda mælingum áfram og skoða próunina yfir tíma. Einnig má benda á að vinnustaðir sveitarfélaganna geta verið mjög ólíkir og störfin ólík. Má par til dæmis nefna starfsumhverfi og vinnuskipulag grunnskólakennara og leikskólakennara og starfsfólks sem vinnur í framkvæmdadeild eða í stjórnsýslunni í skrifstofuvinnu. Frekari greining á gögnunum er pví æskileg með petta í huga og skoða hvort greina megi mun á helgun, starfsánægju og löngun til að hætta í starfi eftir vinnustöðum eða störfum. Í framtíðarrannsókn mætti einnig skoða hvernig helgun í starfi tengist vinnuálagi, streitu og kulnun en pað eru pættir sem einnig tengjast vinnuskipulagi og starfsumhverfi og hafa áhrif á líðan á vinnustað.

Раð skiptir miklu fyrir starfsfólk sveitarfélaganna að starfsfumhverfi pess sé pannig að pað stuðli að aukinni vellíðan á vinnustað og að upplifun pess sé að starf peirra sé mikilvægt og gefandi. Niðurstöður pessarar rannsóknar gefa til kynna að starfsfólk sveitarfélaganna upplifi starfsumhverfið sitt ekki pannig. Рað er pví mikilvægt að stjórnendur sveitarfélaganna taki pessar niðurstöður alvarlega og stuðli að betra vinnuskipulagi og starfsumhverfi starfsfólki til heilla.

\section{Heimildir}

Baptiste, N. (2008). The symbiotic relationship between HRM practices and employee well-being: a corporate social responsibility perspective, The Ashgate Research Companion to Corporate Social Responsibility. doi: 10.4324/9781315612843.ch8

Bakker, A. B., Albrecht, S. L. og Leiter, M. P. (2011). Key questions regarding work engagement. European Journal of Work E Organizational Psychology, 20, 4-28.

Bakker, A. B. og Bal, P. M. (2010). Weekly work engagement and performance: A study among starting teachers. Journal of Occupational and Organizational Psychology, 83(1), 189-206.

Bakker, A. B., \& Demerouti, E. (2008). Towards a model of work engagement. Career Development International, 13, 209-223.

Bakker, A. B. og Leiter, M. P. (Ritstj.). (2010). Work engagement: A handbook of essential theory and research. New York: Psychology Press.

Bolon, D.S. (1997). Organizational citizenship behavior among hospital employees: a multidimensionalanalysisinvolvingjobsatisfactionandorganizationalcommitment. Hospital \& Health Services Administration, 42 (2), 221-241.

Chan, M. F., Luk, A. L., Leong, S. M., Yeung, M. S. og Van, I. K. (2008). Factors influencing Macao nurses' intention to leave current employment. Journal of Clinical Nursing 18, 893-901. 
Cohen, J. W. (1988). Statistical power analysis for the behavioral science (2. útgáfa). Hillsdale, NJ: Lawrence Erlbaum Associates.

Coomber, B. og Barriball, K. L. (2007). Impact of job satisfaction components on intent to leave and turnover for hospital-based nurses: a review of the research literature. International Journal of Nursing Studies 44, 297-314.

De Gieter, S., Hofmans, J. og Pepermans, R. (2011). Revisiting the impact of job satisfaction and organizational commitment on nurse turnover intention: an individual differences analysis. International Journal of Nursing Studies 48, 1562-1569.

Demerouti, E. og Cropanzano, R. (2010). From thought to action: Employee work engagement and job performance. Í A. B. Bakker og M. P. Leiter (ritstjórar.), Work engagement: A handbook of essential theory and research (bls. 147-163). New York, NY: Psychology Press.

Demerouti, E., Bakker, A.B., Nachreiner, F. og Schaufeli, W.B. (2001). The job demands-resources model of burnout. Journal of Applied psychology, 86 (3), 499-512. doi: 10.1037/0021-9010.86.3.499

Eldor, L. og Harpaz, I. (2016). A process model of employee engagement: Learning climate and its relationship with work performance. Journal of Organizational Behavior, 37(2), 213-235.

Fisher, C. D. (2010). Happiness at work. International Journal of Management Reviews, 12 (4), 384-412.

Gallup, Inc. (2013). State of the Global Workplace: Employee Engagement Insights for Business Leaders. Gallup, Inc. Sótt af 12. ágúst 2017 af http://ihrim.org/Pubonline/Wire/Dec13/GlobalWorkplaceReport_2013.pdf

Grant, A. M., Christianson, M. K. og Price, R. H. (2007). Happiness, health, or relationships? Managerial practices and employee well-being tradeoffs. Academy of Management Perspectives, 21 (3), 51-63. doi:10.5465/ amp.2007.26421238

Gravetter, F. J. og Wallnau, L. B. (2004). Statistics for the behavoral sciene (6. útgáfa). Belmont, CA: Wadsworth.

Hakanen, J. J., Bakker, A. B. og Schaufeli, W. B. (2006). Burnout and work engagement among teachers. Journal of School Psychology, 43(6), 495-513.

Halbesleben, J. R. B. og Wheeler, A. R. (2008). The relative role of engagement and embeddedness in predicting job performance and turnover intention. Work and Stress, 22, 242-256.

Harter, J. K., Schmidt, F. L. og Hayes, T. L. (2002). Business-unit-level relationship between employee satisfaction, employee engagement, and business outcomes: a meta-analysis. Journal of Applies Psychology, 87 (2), 268-279.

Kahn, W. A. (1990). Psychological conditions of personal engagement and disengagement at work. Academy of Management Journal, 33, 692-724.

Kalleberg, A. L. (1977). Work values and job rewards: A theory of job satisfaction. American Sociological Review, $42(1), 124-143$.

Lambert, E. G., Hogan, N.L., og Barton, S. M. (2001). The impact of job satisfaction on turnover intent: a test of a structural measurement model using a national sample of workers. The Social Science Journal, 38 (2), 233-250. doi:10.1016/S0362-3319(01)00110

Laschinger, H. K. S. og Finegan, J. (2005). Empowering nurses for engagement and health in hospital settings. Journal of Nursing Administration, 35 (10), 439-449.

Laschinger, H. K. S. og Leiter, M. P. (2006). The impact of nursing work environments on patient safety outcomes: the mediating role of burnout/engagement. The Journal of Nursing Administration, 36 (5), 259-267.

Locke, E. A. (1976). The nature and causes of job satisfaction. In M. Dunette (Ritstj.) Handbook of industrial and organizational pshychology (bls. 1297-1349). Chigago: Rand-McNally.

Macey, W. H. og Schneider, B. (2008). The meaning of employee engagement. Industrial \& Organizational Psychology: Perspectives on Science and Practice, 1, 3-30.

Meyer, J. P., Becker, T. E. og Vandenberghe, C. (2004). Employee commitment and motivation: a conceptual analysis and integrative model. Journal of Applied Psychology, 89 (6), 991-1007.

Owens, R. G. (1991). Organisational Behavior in Education (4. útg.). Needham Heights: Prentice Hall.

Page, K. M. og Vella-Brodrick, D. A. (2009). The 'what,' 'why' and 'how' of employee well-being: A new model. Social Indicators Research, 90 (3), 441-458. doi:10.1007/s11205-008-9270-3

Porter, L. W., Steers, R. M., Mowday, R. T. og Boulian, P. V. (1974). Organizational commitment, job satisfaction, and turnover among psychiatric technicians. Journal of Applied Psychology, 59 (5), pp. 603-609.

Rothbard, N. P. og Patil, S. V. (2010). Being there: Work engagement and positive organizational scholarship. Í K. Cameron og G. Spreitzer (ritstjórar.), The Oxford handbook of positive organizational scholarship (bls. 56-69). Oxford, UK: Oxford University Press.

Saari, L. M., og Judge, T. A. (2004). Employee attitudes and job satisfaction. Human Resource Management, 43 (4), 395-407.

Salanova, M., Agut, S. og Peiro, J. M. (2005). Linking organizational resources and work engagement to employee performance and customer loyalty: The mediation of service climate. Journal of Applied Psychology, 90, 1217-1227.

Schaufeli, W. B. og Bakker, A. B. (2004). Job demands, job resources, and their relationship with burnout and engagement: A multi-sample study. Journal of Organizational Behavior, 25 (3), 293-315. 
Schaufeli, W. B. og Bakker, A. B. (2010). The conceptualization and measurement of work engagement. Í A. B. Bakker og M. P. Leiter (ritstjórar), Work engagement: A handbook of essentioal theaory and research (bls. 10-24). New York: Psychology Press.

Schaufeli, W. B., Taris, T. W. og Van Rhenen, W. (2008). Workaholism, burnout, and work engagement: Three of a kind or three different kinds of employee well-being? Applied Psychology: An International Review, 57 (2), 173-203.

Shuck, M. B. (2011). Four emerging perspectives of employee engagement: An integrative literature review. Human Resource Development Review, 10, 304-328.

Shuck, M. B., Ghosh, R., Zigarmi, D., og Nimon, K. (2013). The jingle jangle of employee engagement: Further exploration of the emerging construct and implications for workplace learning and performance. Human Resource Development Review, 12, 11-35.

Shuck, M. B. og Reio, T. (2011). The employee engagement landscape and HRD: How do we link theory and scholarship to current practice? Advances in Developing Human Resources, 13, 419-428.

Shuck, M. B., Reio, T. G., Jr. og Rocco, T. (2011). Employee engagement: An examination of antecedent and outcome variables. Human Resource Development International, 14, 427-445.

Shuck, M. B. og Wollard, K. (2010). Employee engagement and HRD: A seminal review of the foundations. Human Resource Development, 9, 89-110.

Spector, P. (1997). Job satisfaction: Application, assessment, causes and consequences. Thousand Oaks, CA: Sage.

Skaalvik, E. M. og Skaalvik, S. (2010). Teacher self-efficacy and teachers burnout: a study of relations. Teaching and Teacher Education, 26, 1059-1069.

Tsai, Y. og Wu S-W. (2010). The relationships between organisational citizenship behaviour, job satisfaction and turnover intention. Journal of Clinical Nursing 19, 3564-3574.

Utriainen, K. og Kyngäs, H. (2011). Ageing hospital nurses' well-being at work: psychometric testing of the dignity and respect in ageing nurses' work scale. Scandinavian Journal of Caring Sciences, 25 (3), 617-624. doi: 10.1111/j.1471-6712.2011.00873.x

Warr, P. (2013). How to think about and measure psychological well-being. Í M. Wang, R. R. Sinclaire og L. E. Tetrick (ritstjórar), Research methods in occupational health psychology: Measurement, design, and data analysis (bls. 76-90). New York, NY: Psychology Press/Routledge.

Wiss, H. M. (2002). Deconstructing job satisfaction: Separating evaluations, beliefs and affective experiences. Human Resorce Management Review, 12 (2), 173-194.

Weiss, H. M. og Brief, A. P. (2001). Affect at work: An historical perspective. Í R. L. Payne og C. L. Cooper (ritstjórar), Emotions at work: Theory, research, and application (bls. 133-164). London: Wiley.

West, J. P. og Berman, E. M. (2009). Job satisfaction of public managers in special districts. Review of Public Personnel Administration, 29, 327-353.

Wright, T. A. (2006). The emergence of job satisfaction in organizational behavior: A historical overview of the dawn of job attitude research. Journal of Management History, 12 (3), 262-277.

Xanthopoulou, D., Bakker, A. B., Demerouti, E. og Schaufeli, W. B. (2009). Work engagement and financial returns: A diary study on the role of job and personal resources. Journal of Occupational and Organizational Psychology, 82, 183-200.

Zembylas, M. og Papanastasiou, E. (2004). Job satisfaction among school teachers in Cyprus. Journal of Educational Administration, 42, 357-374. 